\title{
IMPLEMENTATION OF SIX SIGMA IN PRODUCT QUALITY CONTROL
}

\author{
Muhamad Erga Elfanda ${ }^{a}$ \\ ${ }^{\text {a }}$ Fakultas Bisnis dan Ekonomika Universitas Islam Indonesia \\ Email: ergaelfanda@gmail.com ${ }^{\text {a }}$
}

\section{ARTICLE HISTORY}

Received:

10 November 2020

Revised

9 February 2021

Accepted:

19 March 2021

Online available:

06 May 2021

Keywords:

Six Sigma, Product

Quality Control,

DMAIC (Define,

Measure, Analyze,

Improve, Control).

\section{ABSTRACT}

Introduction: The problem faced by the company is the increase in the number of damaged products during the production process, which affects the quality of the product resulting decreased sales levels. The production process in food, beverage, and other processing industry is the most important activity to produce products that later to be marketed.

Methods: The research method used in the study is Six Sigma method. Six Sigma is a system which has purpose to make a business become successful in a comprehensive and flexible manner. The product taken and examined is the sweet fermented Carica fruit. This fruit will be produced by CV. Gemilang Kencana, wheresoever the fruit is ready for the packing process, both cups and bottles.

Results: The results of the calculation of Six Sigma value from CV. Gemilang Kencana has a sigma level 3.8 with the possibility of damage/ defects to the product up to 11,760 pcs in a million chance of production (DPMO). To reduce the number of damaged/ defective products that occur in the production process by sorting the highest percentage of causes damage, namely packaging leakage by $37 \%$, untidy products by $50 \%$, and less full products by $13 \%$.

Conclusion and suggestion: After knowing the results in this study, if the cause of the damage is not handled properly, more products will fail during the production process, which will cause an increase in production costs and have an impact on company losses. 


\section{INTRODUCTION}

The increase in the number of tourist attractions, especially natural tourism in Indonesia, has an effect on the density of activities in this modern era, and the high mobility also increasing number of tourists visiting Indonesia, of course provide the opportunities for souvenir producers to introduce souvenir products in each area and make these products an icon which means the areas where many natural attractions exist have their own characteristics in the field of food. This business is quite promising because tourists who visit a tourist spot often buy souvenirs to be brought when they return home.

Wonosobo Regency is a center on producing vegetable and fruit commodities. One of the regional iconic products of Wonosobo Regency is in the form of fruit carica (Carica Pubescens) which belongs to the papaya family or "Gandul Dieng" like local residents called. The activity of processing carica fruit products in Wonosobo Regency will produce carica sweets or known as carica in syrup (Carica in Syrup). Carica sweets products are marketed in pre-cooked conditions and packaged in various kinds of packaging from glass bottles to plastic cups. So far, carica sweets are marketed in various places both in traditional markets around Dieng tourist attractions and souvenir shops in Dieng. In addition, there are also several producers of carica sweets that have marketed their products outside Dieng area and even outside the city of Wonosobo.

In ISO 8402 (Quality Vocabulary), quality is defined as the totality of the product characteristics that supports its ability to satisfy specified or defined needs. Quality is often defined as customer satisfaction or conformance to the needs or requirements (conformance to the requirements). Here the product can be tangible, intangible, or a combination of both. According to Russell (1996) quality has a very important role for the company, including increasing the company's reputation, reducing costs, increasing market share, and product responsibility.

The large number of opportunities as well as the increasing number of tourists each year do not rule out the possibility that there will be very tight business competition for marketers and producers in souvenir industry. From the existing competition, the producers compete with each other on marketing their products and get consumers trust by improving the quality of their products starting from quality raw materials taken from fresh carica fruit to quality production processes, so it can increase the value of carica sweets product. Furthermore, product quality also supports the resilience of products which are marketed to various regions apart from Dieng, therefore quality plays a very important role so that producers must consider the quality very well because product quality is a potential strategy to beat competitors. The ability of product quality to perform various functions including durability, reliability, accuracy, and ease of use (Kotler and Amstrong 2008). 
One of the fruit processing industries which is quite developed and has become the leading industry in Wonosobo Regency CV. Gemilang Kencana. This CV is a company that engaged in food processing which involves the production process and quality control. The production process that is carried out is producing Carica fruit. Preservation carried out by CV. Gemilang Kencana is a combination of physical treatment with chemical preservation, namely heating and preservation using a sugar solution. In food processing industry, product quality is very concerned because it involves safety and consumer satisfaction. To be able to maintain product quality and achieve results as expected in the processing process, especially the manufacture of carica sweets, it is necessary to apply good and correct processing technology as well as control of product quality starting from handling raw materials to the final product.

Based on some of the problems faced by the company, some symptoms arises from the increase of damaged products during the production process, which affects the product quality that results in decreased sales levels. In food, beverage, and other processing industries, the production process is the most important activity to produce marketed products.

\section{LITERATURE REVIEW}

\section{The traditional society}

\section{Operational management}

According to Render \& Heizer (2005) the definition of operational management is a series of activities that generate value in the form of goods and services by converting inputs into outputs. Subagyo (2000) defined the operational management as the application of management science to regulate all production or operational activities so that they can be carried out efficiently. According to Daft (2006) the definition of operational management is a field of management that focusing on the goods production by using special tools and techniques to solve production problems.

\section{Quality}

Goetsch Davis in Yamit (2005) defined quality as a dynamic condition associated with a product, service, human, process, and environment that meets an expectation. The approach used by Goetsch Davis reinforces that quality does not only emphasize the final result, namely products and services, but also human quality and environmental quality. It would be impossible to produce quality products and services without going through the assembly of quality human and processes.

W. Edwards Deming in Zulian Yamit (2005) also defined quality as everything that becomes the needs and desires of consumers in any form. Philip B. Crosby argued that quality as zero defects, perfection and conformity of requirements, which means zero defects is the absence of damage product so that affect consumer satisfaction. 


\section{Quality Management}

The definition of quality management or integrated quality management according to Vincent Gaspersz (2009) is a way to continuously improving performance (continuous performance improvement) at every level of operation or process, in every functional areas of an organization, by using all available human and capital resources.

According to ISO 8402 (Quality Vocabulary), quality management is all activities of the overall management function that determines quality policies, goals and responsibilities, also implements them through instruments such as quality planning, quality control, quality assurance, and quality improvement. An explanation of quality management instruments can be seen below:

1. Quality planning is the establishment and development of goals also requirements for quality and the application of quality system.

2. Quality control is a technique and operational activity used to fulfill the quality requirements.

3. Quality assurance is all planned and systematic action which implemented and demonstrated to provide sufficient confidence that the product will satisfy the need for a certain quality.

4. Quality improvement is an action taken in order to increase product value for customers by increasing the effectiveness and efficiency of processes and activities through the organizational structure.

\section{Issues in Quality Management}

According to Vincent Gazpersz (2009) the main issues in the application of quality management in an organization or company are:

1. The product development cycle should be shortened through participatory planning, concurrent engineering, and training for planners about quality management methods and tools.

2. Supplier relation should be improved. The number of suppliers should be reduced. A teamwork relation should be established based on mutual trust. The length of the contract should be extended becomes a long-term relationship.

3. Training should be oriented on business results, not on intruments. The main purpose of training should change employee behavior not just training or educating. For example, training in quality improvement should be preceded by the task of tackling a quality improvement project. The training mission should help the quality improvement team to complete quality improvement projects.

\section{The Importance of Quality Management for Companies}

Russell (1996) argued that quality is considered very important for an organization because: 
1. To improve the company's reputation. A company that has produced a quality product or service will get the title as an organization that puts quality first.

2. Cost reduction. By producing quality products, company will achieve an effective and efficient production activity. Because the products produced are suitable with the needs and expectations of customers. Other than that, by implementing strict quality control, the company will avoid activities to produce products or services that are not needed by customers.

3. Increasing market share. The market share of an organization will be achieved when cost minimization is achieved, because the organization or company can reduce prices, even though quality remains the main thing.

4. Product responsibility. The increasing competition for the quality of the product or service produced, the organization will be required to be more responsible on the design, process and distribution of these products to fulfill customer needs and expectations.

\section{Six Sigma}

According to Pande et al. (2002) Six Sigma is a comprehensive and flexible system to achieve and succeed a business. Six Sigma is not a company or owner who controls but everything is governed by customer needs which will improve business processes. According to Widjaja (2002) The Six Sigma method is a comprehensive and flexible system to provide support and maximize business or business processes which focus more on paying attention to customer needs, adjustment, improvement, and reviewing the business or business process. From the two definitions above, we can conclude that the Six Sigma Method from a business perspective is a comprehensive and flexible system on assessing the process management of a business that aims to increase production, reduce product defects by using statistics and problem solving tools.

Six Sigma methodology uses statistical tools to identify the factors that most determine on improving the quality process and will generate profits consisting of 5 stages which is commonly called the DMAIC method.

1. (Define) defines a project.

2. (Measurement) measures the performance of the product manufacturing process.

3. (Analyze) analyze what causes defects in a product.

4. (Improve) the process when repairing defective products.

5. (Control) able to control the processes that have been carried out.

DMAIC is a process to continuously improve products towards Six Sigma targets. DMAIC is carried out systematically based on existing knowledge and facts. DMAIC is a closed-loop process that eliminates unproductive processes causing product defects that usually focus on new measurements and apply technology to improve quality towards Six Sigma targets. 


\section{RESEARCH METHODS}

The research method used is the Six Sigma method. Six Sigma is a system which has purpose to make a business successful in a comprehensive and flexible way. The basis of the main benchmarks of Six Sigma, namely the standards set by the company on how the company understands and able to control the desired quality so that later will know which things that need to be improved for the success of business processes.

Six Sigma methodology includes DMAIC Pete \& Holpp (2002) which stands for Define, Measure, Analyze, Improve, Control. The population in this study are all carica sweets producers in Wonosobo district with production scale above $400 \mathrm{~kg}$ of carica fruit per day. The product taken and researched is the Carica sweets. CV Gemilang Kencana that has gone through the production stage and ready for the packing process, both cups and bottles. While the researchers take 30 pieces of samples for each product which is done every day in data collection process.

\section{RESULT AND ANALYSIS}

\section{Implementation of Quality Control at Carica Gemilang}

The analysis results of research data using the Six Sigma method which consists of five analysis stages, namely define, measure, analyze, improve, and control at Carica Gemilang are as follows:

\section{Define}

Define is the defining stage of the product quality of Carica Gemilang, at this stage it defines several causes of defective products. Based on the data it can be defined that there are 3 components of product damage, namely:

1. Density

2. Leaks

3. Neatness

\section{Measure}

When carrying out product quality control, the first step that must be taken is to create a Check Sheet which has function to simplify the data collection process and perform analysis. In addition, the Check Sheet is also useful for finding out which parts have problems and making it easier to make decisions in order to improve the quality of the production process. The following is a sample of production data and defective product from Carica Gemilang in the first week of May 2019:

Table 1

Carica Gemilang Product Samples Report the first week of May 2019

\begin{tabular}{llc}
\hline Date $\quad$ Cup & Bottle \\
\hline
\end{tabular}


Jurnal Ekonomi dan Bisnis Airlangga, Vol. 31, No. 1, December - May 2021

\begin{tabular}{ccccccc}
\hline & $\begin{array}{c}\text { Product } \\
\text { Total }\end{array}$ & $\begin{array}{c}\text { Defective } \\
\text { Product } \\
\text { Total }\end{array}$ & $\begin{array}{c}\text { Defective } \\
\text { Product } \\
\text { Percentage }\end{array}$ & $\begin{array}{c}\text { Product } \\
\text { Total }\end{array}$ & $\begin{array}{c}\text { Defective } \\
\text { Product } \\
\text { Total }\end{array}$ & $\begin{array}{c}\text { Defective } \\
\text { Product } \\
\text { Percentage }\end{array}$ \\
\hline 1 May 2019 & 4365 & 41 & $0,90 \%$ & 415 & 20 & $4,80 \%$ \\
2 May 2019 & 3405 & 38 & $1,10 \%$ & 305 & 14 & $4,50 \%$ \\
3 May 2019 & 4860 & 33 & $0,60 \%$ & 460 & 19 & $4,10 \%$ \\
4 May 2019 & 5578 & 46 & $0,80 \%$ & 524 & 20 & $3,80 \%$ \\
7 May 2019 & 3872 & 29 & $0,70 \%$ & 376 & 13 & $3,40 \%$ \\
8 May 2019 & 4878 & 48 & $0,90 \%$ & 454 & 26 & $5,70 \%$ \\
\hline Total & 26.958 & 235 & $5,00 \%$ & 2.534 & 112 & $26,30 \%$ \\
\hline Average & & & $0,698 \%$ & & &
\end{tabular}

\section{Source: Processed data}

Data collection at Carica Gemilang is a quality control as measured by the number of final products. Measurements are made using Statistical Quality Control (P-Chart) for the final product in the first week of May 2019. The number of Carica sweets produced from May 1-8 2019 was 29,492. UCL (Upper Control Limit) or the upper limit or the highest limit determined by the company is $5 \%$ of all products made per day, if more than $5 \%$ then the company can be said having profit loss. This means that the company's control over defective products showing defect levels is above average, so that need to be suppressed by improving the quality control system.

Table 2

The Amount of Damage on Sampling

\begin{tabular}{cccccc}
\hline Day & $\begin{array}{c}\text { Fullness of } \\
\text { Content }\end{array}$ & Leaks & Unneat & Amount & Percentage \\
\hline 1 May 2019 & 3 & 0 & 1 & 3 & $10 \%$ \\
2 May 2019 & 0 & 4 & 0 & 4 & $13,33 \%$ \\
3 May 2019 & 2 & 0 & 0 & 2 & $6,66 \%$ \\
4 May 2019 & 0 & 0 & 4 & 4 & $13,33 \%$ \\
7 May 2019 & 0 & 3 & 0 & 3 & $10 \%$ \\
8 May 2019 & 1 & 0 & 0 & 1 & $3,33 \%$ \\
\hline Total & & & & 17 & $56,67 \%$ \\
\hline
\end{tabular}

Table 3

Discussion of DPMO Six Sigma Conversion Tables 
Muhamad Erga Elfanda

\begin{tabular}{ccccccc}
\hline No & Date & $\begin{array}{c}\text { Production } \\
\text { Total }\end{array}$ & $\begin{array}{c}\text { Defective } \\
\text { Product }\end{array}$ & DPU & DPMO & Sigma Value \\
\hline 1 & 01-May-2019 & 4.780 & 61 & 0,012 & 12.000 & 3,7 \\
2 & 02-May-2019 & 3.710 & 52 & 0,014 & 14.000 & 3,7 \\
3 & $03-$ May-2019 & 5.320 & 52 & 0,009 & 9.000 & 3,8 \\
4 & 04-May-2019 & 6.102 & 66 & 0,010 & 10.000 & 3,8 \\
5 & $07-$ May-2019 & 4.248 & 42 & 0,009 & 9.000 & 3,8 \\
6 & $08-$ May-2019 & 5.332 & 74 & 0,013 & 13.000 & 3,7 \\
\hline Total & & 34.560 & 347 & & & \\
\hline Average & & & & & & \\
\hline
\end{tabular}

Based on the table above, the production section of CV. Gemilang Kencana has a sigma level of 3.8 with a possible damage of 11,760 for every one million productions. Of course, if no further evaluation is carried out, it will have an impact on the losses borne by the company because more products are damaged the production process will experience an increase in costs.

\section{Analyze}

Table 4

Damage Type Classification Table

\begin{tabular}{cccccccc}
\hline \multirow{2}{*}{ No } & \multirow{2}{*}{ Date } & \multicolumn{2}{c}{ Fullness of Content } & \multicolumn{2}{c}{ Leaks Package } & \multicolumn{2}{c}{ Unneat } \\
\cline { 3 - 8 } & & Cup & Bottle & Cup & Bottle & Cup & Bottle \\
\hline 1 & 01-May-2019 & 14 & 9 & 17 & 11 & 10 & 0 \\
2 & $02-$ May-2019 & 15 & 6 & 14 & 8 & 9 & 0 \\
3 & $03-$ May-2019 & 10 & 10 & 19 & 9 & 4 & 0 \\
4 & $04-$ May-2019 & 14 & 8 & 21 & 12 & 11 & 0 \\
5 & $07-M a y-2019$ & 9 & 4 & 16 & 9 & 4 & 0 \\
6 & $08-$ May-2019 & 18 & 12 & 23 & 14 & 7 & 0 \\
\hline
\end{tabular}




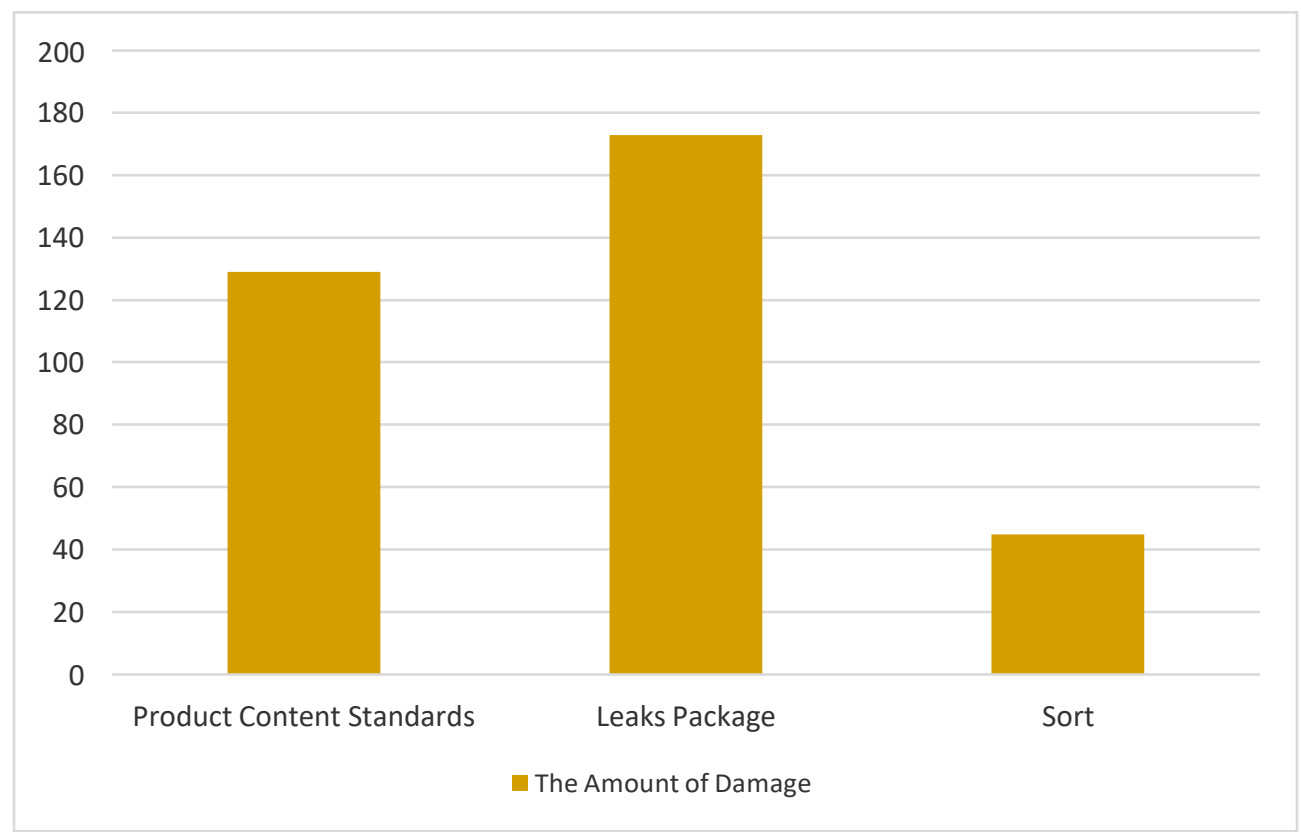

Figure 1

Pareto Diagram

The causes of the product being unfit for sale to the market include non-conformity with product content standards, leaked product packaging, and sorted products. Based on the causes of product damage that have been described, the percentage for products that do not comply with standards is $37 \%$, then for the amount of packaging leakage percentage is $50 \%$, and for the percentage of sorted products is $13 \%$.

Based on the description above, what the company needs to do to repair and reduce defective or damaged products must be focused on the 3 types of damage cause above, namely non-conformity of product content standards, leaking product packaging, and products that fall into the sort category. 


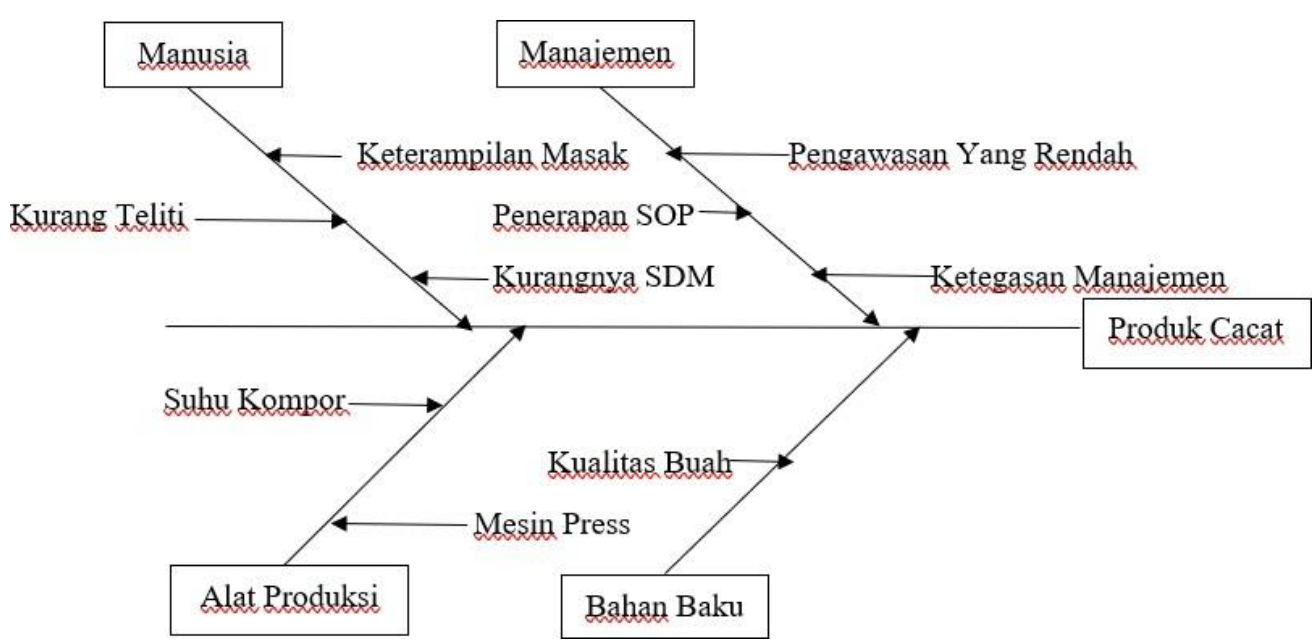

Figure 2

Fishbone Chart

Table 5

Cause and Effect Diagram Analysis

\begin{tabular}{|c|c|c|c|}
\hline No & Factor & Cause & Effect \\
\hline 1 & Human & $\begin{array}{ll}\text { - } & \text { Cooking Skills } \\
\text { - } & \text { Lack of } \\
& \text { thoroughness }\end{array}$ & $\begin{array}{l}\text { - The cooking process is not in accordance } \\
\text { with the predetermined time so that the } \\
\text { results may be too cooked or } \\
\text { undercooked. } \\
\text { - Not being careful in sorting the fruit or } \\
\text { doing the peeling so that the fruit is not } \\
\text { completely clean or there is skin that has } \\
\text { not been peeled off. }\end{array}$ \\
\hline 2 & Management & $\begin{array}{ll}\text { - } & \text { Lack of } \\
\text { - } & \text { Impervison. } \\
\text { on of COS } \\
\text { (Company } \\
\text { Operating } \\
\text { Standards) } \\
\text { Management } \\
\text { assertiveness } \\
\text { of the } \\
\text { company }\end{array}$ & $\begin{array}{l}\text { - Lack of supervision results in workers not } \\
\text { working in accordance to COS so that } \\
\text { increase the level of product damage. } \\
\text { - The implementation of cOS that are not } \\
\text { balanced with assertiveness of } \\
\text { management so the workers only start } \\
\text { working at their will. }\end{array}$ \\
\hline
\end{tabular}


Jurnal Ekonomi dan Bisnis Airlangga, Vol. 31, No. 1, December - May 2021

\begin{tabular}{|c|c|c|c|}
\hline 3 & $\begin{array}{l}\text { Production } \\
\text { Tools }\end{array}$ & $\begin{array}{ll}\text { - } & \text { Stove } \\
\text { temperature } \\
\text { - } & \text { Press } \\
\text { machine }\end{array}$ & $\begin{array}{l}\text { - The amount of temperature affects the } \\
\text { texture of the fruit produced after } \\
\text { processing. } \\
\text { - Press machines that are damaged can } \\
\text { cause leaks in the packaging. }\end{array}$ \\
\hline 4 & Raw material & $\begin{array}{l}\text { - Quality of } \\
\text { fruit }\end{array}$ & $\begin{array}{l}\text { - The level of freshness and ripeness of the } \\
\text { fruit can affect the resulting product. }\end{array}$ \\
\hline
\end{tabular}

Improve

Table 6

Corrective Action Diagram Analysis

\begin{tabular}{|c|c|c|c|}
\hline No & Factor & Cause & Proposed Corrective Action \\
\hline 1 & Human & $\begin{array}{l}\text { - Cooking Skills } \\
\text { - Lack of } \\
\text { thoroughness }\end{array}$ & $\begin{array}{l}\text { - Conduct regular training and evaluating } \\
\text { after the production process. } \\
\text { - From the results of the training, it is } \\
\text { expected that employees can be more } \\
\text { careful on doing everything related to } \\
\text { the production process. }\end{array}$ \\
\hline 2 & Management & $\begin{array}{l}\text { - Lack of } \\
\text { supervison. } \\
\text { - Implementation of } \\
\text { COS (Company } \\
\text { Operating } \\
\text { Standards) } \\
\text { - Management } \\
\text { assertiveness of } \\
\text { the company }\end{array}$ & $\begin{array}{l}\text { - Increase awareness of the importance } \\
\text { on supervising employees. } \\
\text { - Applying the correct cos and } \\
\text { conducting the correct outreach. } \\
\text { - Act decisively in providing rewards and } \\
\text { punishments. }\end{array}$ \\
\hline 3 & $\begin{array}{l}\text { Production } \\
\text { Tools }\end{array}$ & $\begin{array}{l}\text { - Stove } \\
\text { temperature } \\
\text { - } \text { Press machine }\end{array}$ & $\begin{array}{l}\text { - Check the stove regularly so the } \\
\text { resulting flame will always be stable. } \\
\text { Press machines also require regular } \\
\text { service and maintenance to prevent } \\
\text { packaging leaks when pressing. }\end{array}$ \\
\hline 4 & Raw Material & - Quality of fruit & $\begin{array}{l}\text { - Employees should be encouraged to be } \\
\text { more careful in sorting fruit. }\end{array}$ \\
\hline
\end{tabular}




\section{Control}

Control is the final analysis stage of the Six Sigma process that focuses on the actions and documentation that have been implemented. The actions in the control are:

1. Actions are taken related to the equipment schedule.

2. Ensure the COS is well visualized so that employees understand about the standardization of the work they do.

3. Record or take notes of all defective products every day as material for evaluating to make future improvements and communicate it to all related employees.

4. Better control of raw material stock (Management material control).

5. Provide rewards \& punishments that are effective and efficient for employees.

\section{CONCLUSION}

Production obtained from CV. Gemilang Kencana from the total number production during the first week of May 2019 is 29,492 Pcs with the number of damaged/ defective products during production is 347 Pcs. The results of Six Sigma value calculation from CV. Gemilang Kencana has sigma level 3.8 with the possibility of damage/ defects products 11,760 pcs in a million chance of production (DPMO). After knowing the results of the study above, if the cause of the damage is not handled properly, more products will fail during the production process, which will cause an increase of production costs and have an impact on company losses. From the available data, it is explained that the factors which often cause damage to the product are the fullness of the product contents as many as 129 Pcs, 173 pcs of leaked packaging, and 45 Pcs of unneat products. Repairs should be focused on CV. Gemilang Kencana to reduce the number of damaged/ defective products that occur in the production process by sorting the highest percentage of the causes of damage, namely packaging leakage by $37 \%$, unneat products by $50 \%$, and products which have not full contents by $13 \%$.

\section{REFERENCES}

Daft, Richard L. 2006. Manajemen, Edisi 6. Jakarta: Salemba Empat.

Gaspersz, Vincent. 2009. Total Quality Management. Jakarta: PT. Gramedia Pustaka Utama.

Kotler, and Amstrong. 2008. Prinsip-Prinsip Pemasaran, Jilid 1 Dan 2, Edisi 12. Jakarta: Erlangga.

Pande, Peter S., Robert P. Newman, and Roland R. Cavanagh. 2002. The Six Sigma Way : Bagaimana GE, Motorola Dan Perusahaan Terkenal Lainya Mengasah Kinerja Mereka. Yogyakarta: Andi.

Pete, and Holpp. 2002. What Is Six Sigma. Yogjakarta : ANDI. 
Render, Barry, and Jay Heizer. 2005. Operations Management. Jakarta: Salemba Empat. Russell, Daniel W. 1996. "UCLA Loneliness Scale (Version 3): Reliability, Validity, and Factor Structure." Journal of Personality Assessment 66(1): 20-40.

Subagyo, Pangestu. 2000. Manajemen Operasi, Edisi Pertama. Yogyakarta: BPFEYogyakarta.

Widjaja, Miranda Tunggal Amin. 2002. Six Sigma: Gambaran Umum Penerapan Proses Dan Metode-Metode Yang Digunakan Untuk Perbaikan. Jakarta: Harvindo.

Yamit, Zulian. 2005. “Manajemen Kualitas Produk Dan Jasa. Edisi Pertama, Cetakan Keempat". Penerbit Ekonisia, Kampus Fakultas Ekonomi UII Yogyakarta. 